\title{
Educational Activities at the Sami Folk High School 1942-1982
}

\author{
Johan Hansson \\ Department of Historical, Philosophical and Religious Studies, Umeå University, Umeå, Sweden \\ Email: johan.hansson@historia.umu.se
}

Received 4 March 2015; accepted 9 June 2015; published 12 June 2015

Copyright (C) 2015 by author and Scientific Research Publishing Inc. This work is licensed under the Creative Commons Attribution International License (CC BY). http://creativecommons.org/licenses/by/4.0/

\section{Abstract}

The Sami folk high school started in 1942 as a school for young Sami that needed more education that the Swedish folk school or nomadic school offered its pupils. The school was managed by the Swedish mission society, an organization within the Swedish church. The school was successful but struggled with financial problems. The result was that a foundation with Sami representation managed the school instead after 1972. The following year was even more successful. The number of students increased, and the management could offer more courses and their curriculum had more Sami elements than earlier. However, there was also some conflicts during the 1970s. The largest one being the language boycott addressing the issue of Sami languages at the Sami folk high school as a subject in the school, and as an important part of the Sami culture and identity. This article describes the education of the Sami folk high school's first 40 years with the help of a model for Sami pedagogy developed by Keskitalo and Määttä. The model shows that the education is to a large extent affected by outer factors-self determination, as well as inner factors-language issues and the curriculum.

\section{Keywords}

Sami, Folk High School, Indigenous Education

\section{Introduction}

The Sami is an indigenous minority in Sweden with their own languages and culture. In Sweden today it is estimated that there are 20,000 - 30,000 Sami. Some 7000 of them speak one of the Sami languages, North Sami being the largest of the language group in the Nordic countries. Nomadic reindeer herding is closely connected with the Sami but it has never been the only way to earn a living for the Sami people in Sweden. Other occupations are, and have been, common as well (Sami Parliament, 2005). Today, the majority of Swedish citizens of Sami ancestry do not work with the reindeer. The Sami people have an educational level similar to other groups 
in the country, as well as a fairly similar life expectancy and income level (Sjölander, Edin-Liljegren, \& Daerga, 2009; Morris, 2009).

In Sweden, primary education became free and available for all children in Sweden in 1842, but children in the rural areas were not offered the same amount of teaching as the children in the more populated areas, and since the children's labor were important for the families' total income, parents weren't always that eager to send their children off to school. During the first part of the 1900s, almost all children went to the public school, the Folk School (Folkskolan). Schooling was six or seven years, beginning the year the pupil turned seven years old. For the reindeer herding Sami children, a separate school system was established in 1913: the Nomadic School (Nomadskolan). There they were supposed to learn arithmetic's, reading, writing and so on, just like in the Folk School. Because of the large distances, the Nomadic School was a boarding school. Other Sami children went to the Folk School. Over the years there was quite a lot of critique of the Nomadic school, so when the school system was reformed during the 1960s, the Nomadic school was changed as well (Sjögren, 2010).

The compulsory school of 1962 (Grundskolan) was a nine-year elementary school for all Swedish children (ages 7 - 16) regardless of ethnic group, class or creed. Sami children had the right to study their mother tongue, but outside of the areas where there were a substantial amount of Sami speakers in the community, this proved to be difficult, and it still is. Today the Sami population is as educated as other groups in the Swedish society. Official statistics says that $50 \%$ of the adult Swedish population today has attended secondary education and 35\% has experience from college or university education. The Sami that are not reindeer herders have the same educational level as other citizens in their regions. Reindeer herding men have a significantly lower level of education than other men, but women in reindeer herding families have a higher educational level than their non-Sami neighbors (Sjölander, Edin-Liljegren, \& Daerga, 2009). During the early 1900s, the situation was different. The government claimed to give the Sami children a good primary education, but the adult Sami was not as educated as other adults in the population. This was identified as a problem by leading Sami as well as other stakeholders such as the Swedish Mission Society (Svenska missionssällskapet, SMS for short).

SMS was founded in1835. During the first years, they set a course which they followed for over 100 years: educating Sami children and spreading the Christian learnings in the Sami community. SMS established schools for children in the rural areas in the northern part of Sweden, the first in 1839, funded by private donations and church collections. They also sent out preachers, as well as teachers to work in the nomadic Sami community. SMS educational efforts were concentrated towards children of the same age as the ones that later on were subject to the Nomadic school, so after 1913 there was little need of SMS schools. Instead they recognized the need of secondary education amongst the Sami. In 1940 the chairman of the SMS, Bengt Jonzon set out to start a Folk high school for the Sami youth. Jonzon was the bishop in the diocese of Luleå, a diocese that covers the northern part of Sweden, where a large part of the Samis traditional lands are.

The Folk high School idea that was realized in 1942 was over twenty years old, originally articulated by leading Sami politicians. The decision to divert the resources of the SMS from primary education to a Folk high school meant that they stayed on their original course: educating the Sami and still spreading the word of Christ. The Sami Folk high School contributed to the schooling of the Sami youth and also played an important role as a meeting place. The role as a place for political work has been researched but not the educational activities at the Sami Folk high school despite its importance for many individual Sami and the whole Sami society. The SMS left the Sami Folk high school in the early 1970s and instead a foundation consisting of representatives from the local authorities and Sami organizations managed the school.

\section{Aim and Research Questions}

The Sami Folk high school was the first attempt at offering the Sami people an education at the secondary level but the educational activities at the school has not been studied earlier. Education for Sami children at the primary-school level in Sweden has been studied earlier, with different time periods in focus. In this article the first 40 years at the Sami Folk high school is investigated. The study has been guided by questions regarding aims of the education, what school subjects were taught and in what way the teaching changed during the 1970s, when the Sami Folk high School was handed over from the SMS to a foundation where the Sami had representation.

\section{Background}

The first Folk high school started in Denmark in 1844. The first Folk high school outside of Denmark was 
founded in the neighboring Sweden in 1868. The Folk high schools' educational aims was specified by the organization that managed it: Christian groups, labor unions, political organizations and so forth. At first there were no degrees given and the learning goals, teaching methods and subject matter was to be decided by the students and teachers together in a democratic spirit—but within the frames given by the managing organization. Another important aspect of the Folk high school was the idea that the school experience should give a kind of social education as well. Therefore the students not only studied together but they also lived together during their time at the Folk high school, often close to the staff in housing provided by the school (Toivalainen, 1995).

The teaching methods used in the first Folk high schools were at first mainly lecturing. Over the years a more conversational and student active version of the lecture evolved. The lectures was supplemented with independent studies, with or without teacher supervision. In some subjects there were frequent laboratory work, practical exercises, and excursions. There are many examples of Folk high schools that were a head of their time regarding pedagogical ideas and teaching methods, as well as their attitudes towards their students (Burgman, 1968). The Folk high schools in general were more progressive than other schools, but they were influenced in many ways by the managing organizations' beliefs or ideology. This manifested itself not only in the preferred teaching methods but also in rules of conduct and offered leisure activities. Even today there are examples of Folk high schools that have stricter rules than what is considered normal for schools in Sweden.

During the mid-1900s a lot of the Swedish youth, often in their late teens or early twenties, complemented their education with a course at a Folk high school. For some of them, that experience led to further studies at a Folk high school, a vocational school, or an upper secondary school. For others the education widened their individual perspectives, or gave a possible competitive advantage on the labor market. The government supported the Folk high schools and gave a substantial contribution to the cost of the teaching in the general course (allmän kurs) which prepared for further studies. Normally the tuition was free for the students. For room and board the student had to pay a small fee, but it was possible for pupils to receive scholarships for that cost. For many young Swedes from rural areas and from low-income families with little or no educational experiences, the Folk high schools were appealing well in to the 1960s. The school reforms during the 1960s affected the popularity some, but the Folk high schools adapted to the new conditions and offered more courses in crafts, art, and music for example. Changes like that meant a small increase in the number of students during the early 1970s and late 1960s (SCB, 1977). At that point the courses in, for example crafts, could receive governmental support as well as the general course.

Today the Folk high schools complements the regular school system in Sweden, They offer alternative ways for adult students to get an education at the upper secondary level as well as specialized courses of varying types, for example in photography, crafts or sign language.

\section{Theory, Method, Sources and Limitations of the Study}

A qualitative method have been used when studying the sources that will be described further down. Postcolonial theories have been a guide when reading the source material, and together with pedagogical theories as well as empirical research they form the basis for a model for Sami pedagogy presented by PiggaKeskitalo and KaatarinaMäättä. Their model explains why Sami pedagogy has its special features and tries to improve education for the Sami in today's schools (Keskitalo \& Määttä, 2011). Keskitalo and Määtä states that Sami pedagogy is a result of inner and outer factors. The outer factors illustrate that Sami education is colored by colonization, acts in a liminal position or in interfaces, acts in the field of multiculturalism and acts within limited self-determination. The inner factors that influence Sami education are: Creating the indigenous peoples' own curriculum based on their own values and knowledge system, strengthening the position of the indigenous peoples' own language, creating cultural-sensitive teaching arrangements, and diversifying the extensive cooperation (Keskitalo, Määttä, \& Uusiautti, 2011). Even though the model is developed for contemporary education it can be used for discussing educational activities in the past as well. It also provides a suitable disposition of the text. All factors influencing Sami education is interesting, but since the research questions are focused on the schools subjects, teaching methods, and aims with the education, the curriculum will be more thoroughly described than the other factors.

The source material mainly consists of protocols from meetings, correspondence and other documents established at SF, now stored in archives in Jokkmokk. This material is supplemented by texts such as publications for members of the SMS. These sources contains the school management's ideas about the education at SF, their 
planning of the schools activities and to some extent the views of the students, the teachers, and the members of the surrounding society regarding the teaching and other activities at the school. Naturally, not all views of what took place can be observed, and the school management's thoughts and actions are more prominent than others. With awareness of that problem, the sources offers an image of the school's teaching and its changes during the period 1942-1982. The research period is chosen so that it covers the start of the school and ten years of the succeeding foundation's management. The foundation had representation from Sami organizations, but the board also had representation from the municipality where the Sami Folk high school was located: Jokkmokk.

\section{Outer Factors}

\subsection{Colonization}

Like many other indigenous people around the world the Sami have been affected by a process of colonization which have had a huge impact on their economy, culture and rights. For the Sami this process really started in the 1500 - 1600s when the Nation-states of the region; Russia, Sweden and Denmark, became interested in defining borders in the area as well as controlling and taxing its inhabitants. During the late 1800s and early 1900s the pressure on the Sami as a people became greater due to the industrialization of Sweden. In their traditional lands, hydro electrical power plants were built, mines was started, railways and roads was constructed. This affected the Samis' traditional vocations, reindeer herding, hunting and fishing a lot. At the same time the government's efforts to educate all Swedish children intensified. For the Sami the educational reforms as well as the changes in the society meant that children of Sami decent were separated from each other due to the separate school system for the reindeer herders children. The Samis children did not learn their native language, and missed other parts of their culture as well (Sami Parliament, 2005).

This situation was viewed as a crisis by Sami leaders as well as individuals and organizations who had become interested in the Sami people. The SMS was one of those organizations, and with their former commitment to educate the Sami, as well as their religious work, it was not a huge step to start a Folk high school for Sami youth. Whether or not the SMS continued to be a part of the colonizing power or not can be debated. Their chairman, Bishop Bengt Jonzon, declared that the Sami people were threatened and therefore, the Sami had certain responsibilities in the Swedish society - to preserve their race, their line of work, their culture and their language. This could of course be viewed as a statement saying that the Sami should be separated from other groups in the society. On the other hand Jonzon wrote that the Sami had the same rights as other people and that it was, to use more modern terms, preferable to integrate rather than assimilate the Sami. The way to achieve that was to let the young generation of Sami gain insights in their own traditions, something that the Sami Folk high school could offer. That education would be a great opportunity to learn the culture as well as to study so that they better could represent their people (Svenska Missionssällskapet, 1942). The principal, Lennart Wallmark wrote about the school in similar terms when describing the aim of the planned first school year (Svenska Missionssällskapet, 1942):

The aim of the course is to impart a general knowledge and practical skills in a Christian spirit, thus preparing the young to better face the demands in life. Special attention will be given all that concerns the Sami's life and work.

So the SMS's idea with the Folk high school was to empower the Sami through education, aid them in preserving their culture, and to instill Christian values. There was no opposition to this from leading Sami at that time, nor from young adult Sami. But, some twenty-five years later, young Sami started to question the frequent Christian features at the school.

When the SMS left the school formally in 1972, the new management more or less kept the aims of their predecessors, leaving religion out of the education though. The largest difference being that then the Sami themselves had a greater influence over what Sami culture that was to be preserved and developed, and what education that was best needed for Sami youth as well as the whole Sami people. But, the new management still had to follow the rules and regulations regarding the Folk high schools in Sweden, just as the SMS had to do in order to receive governmental funding.

\subsection{Liminal Position}

One of the factors that influences Sami pedagogy is its liminal position. This means that education for the Sami 
exists on many borders both physical and mental. Keskitalo’s and Määttä’s reasons whether or not the school culture is in tune with the Sami families' culture, the ideal being a school culture that has the same values as the children's families and a school that benefits from the Sami culture and values (Keskitalo \& Määttä, 2011). Since this was a Folk high school the pupils were no longer children, most of them were in their late teens or early twenties. They had been fostered in both their families' and their schools' values. They all had individual experiences, skills, values and therefore all students had differences in their identities. Consequently it is likely that the culture at the Sami Folk high school did not correspond to all students' culture.

During the period of the SMS's management the culture at the school had religious influences, and even though the principal had great knowledge about the Sami and a will to improve their situation, he did not fully adapt the school to his students' culture. Instead he set out to foster them in what he and the SMS thought were the correct values. Sometimes they were the same as the pupils', and sometimes not, depending on the pupils individual experiences. In the last years of Wallmark's period of being the principal there were more conflicts between him and his students. This was not necessary because of the liminal position of the education. It is more likely that it was connected to the changes in the society as a whole. During the 1960s the youth culture became more questioning. Young Sami was influenced by this culture, just as other young people in Sweden. One effect of this change in the attitudes of youth in Sweden was that young people became more sceptic to religion, a change that could have been problematic for Wallmark. The foundation that later gained management of the school did not have the same ambition to foster the students in religious values and the staff was more open to their pupils' different cultures, whether Sami or not.

The change of management meant that there also was a small change of the school culture. This change showed itself for example when young Sami demonstrated against the US involvement in Vietnam during a visit at the school by the US ambassador in 1973 (Samernas Utbildningscentrum, 2013). A demonstration like that could not have happened during the management of the SMS.

\subsection{Multiculturalism}

Keskitalo and Määtä explains with the help of Vuokko Hirvonen that schools for Sami have varying levels of multiculturalism. The highest level means a truly multicultural school where the students are trained in social criticism and assuming responsibility as well as gaining general knowledge and gaining insights in their Sami culture. None of the schools that Hirvonen studied had reached that level (Hirvonen, 2004; Keskitalo \& Määttä, 2011). The other three levels describes a schools degree of integration: the first one being a level where the school adds single Sami elements to the education, the second level adds Sami contents, themes and perspectives to an education that has the same structure as before, and at the third level the structure is changed so students can view events, issues and so forth from a Sami perspective. Hirvonen had in her studies observed schools at those three levels, the third one being the least frequent (Keskitalo \& Määttä, 2011).

During the period that the education at the Sami Folk high school have been studied there were attempts to reach the fourth level during the foundations management as well as the SMS's. The ambition was to, through education, empower the pupils so that they could improve their own situation as well as their people. However, it is obvious that the fourth level was never reached. In fact, the first and second level best describes the school. Wallmark's first curriculum contained a large percentage of more practically orientated subjects; all based on his idea on what was Sami and what Sami youths needed. But, in order to get governmental funding for the school, it was necessary to follow the national curriculum for the general course. This meant that most of the subjects' contents and teaching were not Sami influenced, but subjects like Sami crafts or Sami languages were added on and they had an obvious Sami theme. Many of the extra-curricular activities that was offered during Wallmark's time as a principal also had Sami connotations, for example visits from Sami scholars, foresters or when doing field trips.

About the time of the foundation taking over the management of the Sami Folk high school there was a change in the government's rules making it easier to offer courses with a theme of some sort. This made it possible for the new staff to organize two longer and clearly Sami coded courses, the crafts course and the Sami Ällin course (roughly translated to Sami Life), as well as the general course and an ecology course, both described further on. The first two offered more of Sami themes and perspectives bordering to the third level but since the basic structure for a Folk high school course was kept, that education didn't reach a higher level. But it is also possible to say that the Sami Folk high school gradually reached a higher level of multiculturalism since 
its start in the 1940s. Then, it was a school exclusively for the Sami and in the late 1960s it opened for pupils of all ethnicities. Parallel with the teaching, the staff also worked for cooperation with Sami in other countries. During the 1970s the international contacts increased and there were contacts made with indigenous people in other parts of the world as well. This cultural exchange was at first an initiative from the SMS but later on became something that the students and young Sami became interested and involved in.

\subsection{Limited Self-Determination}

Leading Sami had a marginal influence in the SMS and the Sami Folk high school. First when the SMS ended its involvement in the school because of financial issues, Sami representatives gained real control over the school through the foundation in 1972. But, the first years of the 1970s the principal was not Sami and many of the teachers wasn't either. This changed when BirgittaÖstlund left her position as a principal to IngwarÅhrén, the first principal at the Sami Folk high school that was of Sami decent in 1976 (Samernas Utbildningscentrum, 2013). The gradual shift in who managed the school and who worked there was a process that started long before the 1970s. During that decade the school's staff as well as management became Sami to a greater extent but this did not mean that the Sami could determine the fate of the school themselves. First of all, there were students and members of the staff who were not Sami, as well as some representatives in the foundation board. Second, and most important, a lot of the questions regarding the Sami Folk high school were determined by the national Swedish school authority (Skolöverstyrelsen). This was the case for all schools in Sweden during that time, and the Folk schools were no exception. Every longer or shorter course as well as workshops of different kinds had to be approved by the authority in order to get funds. The school authority also had a say in who could be employed as a teacher.

The school authority limited the autonomy for the school, but on the other hand it rarely objected to educational initiatives from the Sami Folk high school and often approved of exemptions from national rules such as the amount of students that was needed in a class in order order to get funding. Keskitalo and Määtä writes that the Sami never have a real influence over Sami educational issues on a macro level (Keskitalo \& Määttä, 2011). This true to a certain degree for the secondary education at the Sami Folk high school as well, but when the foundation took over the management of the school and the school authority's rules for funding the Folk high schools courses changed, the self-determination increased some. They could adjust the rules some, but not change the game completely.

\section{Inner Factors}

\subsection{Curriculum}

A curriculum could be just a document describing the education. On the other hand you could view curriculum as many aspects of education. This is the case in Keskitalo's and Määtä's model. They use John Goodlads five levels of curriculum when describing and arguing for a Sami curriculum. The first level is the ideological level, describing the society's ideas and conceptions. The second level is the formal one, shown in laws, rules and other documents, describing the school system. The third level is the interpretive curriculum and it shows how the users understand the texts in the formal curriculum. The fourth level is the implemented curriculum, for example a teacher's action in a classroom. The fifth level is the experienced curriculum, which is the students' experiences during the education. These five levels of curriculum covers more or less every aspect of a school or an education - from pedagogical ideas to a pupil's thoughts of what clothes are appropriate to wear at school (Keskitalo \& Määttä, 2011). The source material for this study consists mostly of written material archived at the school, mostly concerning curriculum at level two, three and four. The other aspects of the curriculum are not as visible in the studied sources.

\subsubsection{SMS's Management}

In their book on Sami pedagogy Keskitalo and Määtä reason about what should be done to improve Sami education and stresses the fact that education for any indigenous people should support that people's culture. A curriculum that combines western knowledge with the knowledge of the indigenous people must be developed in cooperation with the community of the indigenous people (Keskitalo \& Määttä, 2011). Given the limitations that the Swedish school authority set up, the management of the Sami Folk high school worked for a curriculum that 
was a combination of skills and knowledge needed in a modern society as well as the Sami's traditional knowledge. Wallmark attempted to make such a curriculum when the school started. However, it was his interpretation of Sami traditional knowledge and what the young Sami of the day needed that guided him in his work. Of course Wallmark had to adjust the curriculum so the school could receive funding for the general course, so during the years of the SMS's management it was to a great extent the Swedish school authority that dictated the curriculum.

Even though the national curriculum was precise in what subjects that should be taught, there were some autonomy for a Folk high school. They could add subjects of their own to the national curriculum. This was done at the Sami Folk high school so the education was not identical to other Folk high schools'. The school's journals shows that the subjects changed some, but not much, over the years. The staffs' competences, the teaching facilities, as well as opportunities to visit relevant places or to get interesting visitors to participate in the teachingaffected both planning and practice. During the 1950s the education consisted of just the general course taught during the winter. There were two grades of it as well as a continuation course, making it possible to study for an additional four weeks after the regular winter course ended in March or April. In Table 1 below it is illustrated what subjects that were taught during the school year 1955-1956. After the mandatory lessons there were often added additional activities - some more for leisure or fun, others with education or fostering in focus. There could for example be visits from visiting Sami leaders, athletic competitions, study trips, screening of film, exhibitions, and performances from students.

\section{Table 1. Subjects 1955-1956.}

\begin{tabular}{|c|c|c|}
\hline \multicolumn{3}{|c|}{ Courses } \\
\hline $\begin{array}{l}\text { The Winter Course } \\
\text { (hours per week) }\end{array}$ & $\begin{array}{l}\text { The Second Winter Course } \\
\text { (hours per week) }\end{array}$ & $\begin{array}{l}\text { The Continuation Course } \\
\text { (hours per week) }\end{array}$ \\
\hline Religion (2) & Religion (2) & Practical Swedish (6) \\
\hline Psychology (2) & Psychology (2) & Current Sami history (3) \\
\hline Swedish (4) & Swedish (4) & Civics (5) \\
\hline Sami languages (2) & Library knowledge (1) & Accounting (4) \\
\hline Literature (3) & Literature (3) & Genetics (2) \\
\hline Sami history, culture and vocations (2) & Sami history, culture and vocations (2) & Dietetics (1) \\
\hline History (3) & History (3) & Household chores (15) \\
\hline Civics (2) & Civics (2) & Singing (2) \\
\hline Geography (2) & Geography (2) & Physical education (2) \\
\hline Health education (2) & Biology (2) & \\
\hline Arithmetic (3) & Arithmetic (3) & Sum: 40 \\
\hline Physics $(1,5)$ & Physics (2) & \\
\hline Chemistry $(1,5)$ & Chemistry (2) & \\
\hline English (3) & English, voluntarily (3) & \\
\hline Accounting (1) & Sami crafts (5) & \\
\hline \multicolumn{3}{|l|}{ Sami crafts (7) } \\
\hline \multicolumn{3}{|l|}{ Library knowledge (1) } \\
\hline \multicolumn{3}{|l|}{ Home economics (1) } \\
\hline Sum: 43 & Sum: 38 & \\
\hline \multicolumn{3}{|l|}{$\begin{array}{l}\text { Subjects taught in both winter courses } \\
\text { (hours per week) }\end{array}$} \\
\hline \multicolumn{3}{|l|}{ Current events (1) } \\
\hline \multicolumn{3}{|l|}{ Song (2) } \\
\hline \multicolumn{3}{|l|}{ Physical educaton and swimming (2) } \\
\hline \multicolumn{3}{|l|}{$\begin{array}{c}\text { Voluntarily Study groups: } \\
\text { Theatre (1) } \\
\text { Issues concerning Reindeer herding (1) }\end{array}$} \\
\hline Sum: 7 & & \\
\hline
\end{tabular}

Source: Wallmark, L. (1956), Samernas folkhögskola-Redogörelse för läsåret 1955-1956, Jokkmokk: Samernas folkhögskola. 
Wallmark added subjects to the curriculum which he figured that the Sami youth and the Sami community needed: current events, Sami languages, Sami crafts and Sami culture, history and vocations. Therefore Schooldays became long, often eleven hours, starting at eight in the morning (Wallmark, 1956).

The general subjects were more or less the same during the first and second winter course, but with some progression. In the history-subject there was a clear focus on chronological knowledge. The first course described the Swedish society's development up to 1809. The teaching also addressed the question of the majority society's relations with the Sami community over the years, and the democratization of the Swedish society. In the second course the focus was on what was called general history, for example ancient Egypt, the antiquity, the middle ages, reformation, the revolutions of the 1800- and 1900-centuries, as well as the conflicts of the 20 :th century and post war era. Except the mentioning of a lecture given by a visiting headmaster, there was no comments of the teaching methods used in the history subject (Wallmark, 1956).

Content wise, the descriptions of the performed teaching shows that the general theoretical subjects were rarely adapted for the Sami group-most topics addressed might as well have been taught at some other Folk high school in Sweden. The teaching methods were common as well: mainly teacher orientated approaches such as lecturing. At times other teaching methods were applied: students leading discussions, essay writing, experiments and so on. There were some technical aids in use: slides or films (Wallmark, 1956). The chosen ways of teaching were not out of the ordinary for schools in Sweden at that time, but maybe on the more conservative side compared with other Folk high schools during the latter part of the 1960-ies.

Christian values and practices were manifested daily in the Sami Folk high school when managed by the SMS. There was mandatory praying and whenever there were a significant Christian holiday it was celebrated at school, if the students were not on leave. This was not unique for this Folk high school, in fact it was common in the compulsory school as well. In the school reform of 1962 it was decided that the compulsory school (ages 7 16) in Sweden should be non-confessional. The Swedish society's changing views on what place religion should have in schools naturally had an impact on the Sami Folk high school, even though it was a Christian Folk high school and therefore they had the ability to decide for themselves what significance the Christian beliefs and traditions would have. During the 1960s the general courses changed some and less time was given to studies of Christian beliefs. The subject matter of the school subject religion was during the first winter course more or less the same through the years: the history of Christianity, studies of texts like the bible or the churches hymnbook and an overview of the Christian beliefs. The subject religion in the second course changed some during the latter part of the 1960s so that other religions of the world than Christianity were studied as well (Wallmark, 1956; Wallmark, 1961; Wallmark, 1966; Wallmark, 1969; Wallmark, 1970). Studies of Christianity were of great importance at the Sami Folk high school as well as in the students' life at the school in general, something that most students seems to have been OK with. But, there were some opposition to Wallmark's intention to instill Christian morality and beliefs. Gradually, there were less of voluntarily religious "off-lesson" activities, starting with the option to not attend Sunday mass. This change was a small adjustment to the students' previous experiences and the changing society. In the 1940s and 1950s, most of the students were used to religious elements in a way that the students of the 1960s were not.

\subsubsection{The Foundation's Management}

When the SMS handed over the management of the school to the foundation there were some changes in the courses offered by the school. The new management kept the general course and the frequent shorter workshops and courses in crafts, bookkeeping or other competences that in some way could be beneficial for the Sami. During the first years of the 1970s the school's staff developed three new long courses: The Crafts course, the Ecology course and the Sami-Ällin course (roughly translated to Sami life-course). The new courses attracted students and the old general course was still interesting for the students even though it was altered some.

The Crafts course offered a possibility to learn skills in crafts, to get increased knowledge in Sami culture and an increased possibility to a future income. The largest difference between this crafts education and the one taught before is that the students to a larger extent were specialized in crafts and did not receive the same education in general theoretical subjects. The students choose between "hard crafts": working with wood, metal and antlers, or "soft crafts": mainly working with fabric and leather. There was teaching in more theoretical subjects as well, for example the students in the early 1980s learned music and Sami languages, but no Swedish or mathematics. During the years 1977-1978 and 1978-1979 one third of the Sami Folk high schools students chose the Crafts course-approximately 20 students per year. During the following years the interest increased, and 
some 25 students studied at the crafts courses, counting both the first and second grade. At the same time the total number of students increased some.

Sami crafts had always been an important part of the education at the Sami Folk high school since its start. But, the times changed and the importance of skills in crafts were not as necessary for the reindeer herders as it once had been due to mechanization. Instead crafts became a possible way of income, a trade on its own terms. At the same time environmental issues started to attract attention from an increasing number of people in the society and tourism started to be a possible way to make a living. Therefore the Ecology course was established. In contrast of the craft course and the general course, the ecology course required that a student had prior studies at the upper secondary school or a Folk high school. The target group was students who planned to study at the university or to work within tourism or nature conservation in the future.

The principal's description of the course explains that human beings are a part of the environment. Since the course was orientated towards the environment in the northern part of the Nordic countries, Sami culture was to be a part of the course's educational contents. The Ecology course contained general subjects, at a level suited for the individual student. In addition to that, there were "special" subjects as well: ecology/outdoor knowledge, sociology/regional planning, communicational skills such as writing or giving speeches and cultural knowledge: observing/reading/interpreting/creating and Sami culture. This content only marginally changed during the years — three themes were mentioned in the study plan of 1981-1982 and 1982-1983: Ecology, Society, and Politics. The other subjects were studied together with students from other courses.

The third new course was the Sami Ällin-course. If the crafts course gave the students the opportunity to improve themselves in the material part of the Sami culture, Sami Ällin was supposed to be orientated towards the immaterial—knowledge in Sami languages, history and society. Sami Ällin had three variations. One with an environmental theme, one with a media theme and one with a language theme. The expected students were those who planned to, or already worked in a vocation where the Sami culture was important, for example as interpreters, language teachers or journalists. These students were expected to have one of the Sami languages as their mother tongue or equivalent skills, as well as theoretical knowledge of it. It might be that these requirements, or uncertainty in what the students were qualified for after their studies, affected the interest for the course. During the years when Sami Ällin was one of the offered courses it was the least popular of the Sami Folk high schools courses as seen in Table 2 below. From 1979 and onwards there were no students registered at the Sami Ällin course due to conflicts at the Folk high school during the school year of 1978-1979. Students with an interest in Sami languages and Sami culture instead got the possibility to learn that within the other courses at the Sami Folkhigh school.

The new courses presented by the foundations first principal, Birgitta Östlund, and her staff were successfulthe number of students increased. The new courses were possible due to changed regulations. A Folkhigh school could then receive governmental funding for other courses than the general course, and some support from funds established by the companies in control of hydro electrical power plants. These power plants had a huge effect on the environment and affected the reindeer herding a lot. Therefore, a small sum of the companies' profits could be given back to projects supporting for example local businesses.

The decrease of students' interest in the Sami Folkhigh school during the 1960-ies is often explained with the changes in the nation's educational system. But, as shown below, just as many students were interested of the

Table 2. Number of students at the sami folk high school, 1977-1982.

\begin{tabular}{|c|c|c|c|c|c|}
\hline \multirow{2}{*}{ Course } & \multicolumn{4}{|c|}{ Courses } & \multirow[b]{2}{*}{ 1981-1982 } \\
\hline & $1977-1978$ & 1978-1979 & $1979-1980$ & 1980-1981 & \\
\hline General course (Allmänlinje) & 21 & 15 & 37 & 33 & 18 \\
\hline Ecology course (Ekologilinjen) & 19 & 19 & 14 & 13 & 12 \\
\hline Sami Ällin course (Sami Ällin) & 7 & 16 & - & - & - \\
\hline Crafts course (Slöjdlinjen) & 20 & 10 & 26 & 26 & 25 \\
\hline Total & 67 & 60 & 77 & 72 & 55 \\
\hline
\end{tabular}

Source:Samernas folkhögskola A1:1, Protokoll Samernas folkhögskolas stiftelse 1972-1981; Samernas folkhögskola F7C:2, Planeringar med mera (Långa kurser) 1977-1983. 
general course during the late 1970-es as during the 1960-ies even though they had access to higher education in other ways. During the school year 1960-1961 there were 29 pupils participating in the schools winter course. During 1965-1966 the number had decreased to 21 students. 1968-1969, the school opened for other students than Sami, then 44 students followed the course. During BirgittaÖstlunds first years as a principal there were 56 students participating in the general course (Wallmark, 1961; Wallmark, 1966; Wallmark, 1969; Östlund, 1971).

As was the case during the prior decades, the Winter Course, in the 1970s called the General Course, changed some from one year to another. The reasons being circumstances such as the competences of the available teachers. The most important alteration was the formation of the Sami crafts course, and a decreased amount of scheduled lectures due to the five day week, introduced in the study year 1968-1969. In the Sami Ällin course the Sami school subjects were in focus, but other students could learn them as well. So, when the Sami Ällin course no longer was available, the general course was the students' second choice. When Sami Ällin had its peak amount of students, the general course had its record low as seen in Table 2. In Table 3, the subjects in the four courses offered at the Sami Folk high school during the 1970s are presented. If compared with the course taught during the 1950s, presented in Table 1, the 1970s did not have as many lessons per week. This was one effect of the five day school week introduced in Swedish schools 1968. Earlier it was a six day week.

At the Sami Folkhigh school the staff, during the 1970s was inventive when it came to proposing workshops and other shorter courses. Many of them was not given because there were too few applicants. Over the years' different kinds of courses in handicraft was the most popular ones. During the school's first decades there were quite a lot of workshops in bookkeeping, writing and other skills useful for the Sami community. This tradition continued the 1970s but changed some. There were still short courses aimed at the Sami as a group, but during the 1970s there was some teaching in cooperation with the local authorities educating unemployed in the area as well. Amongst one of the more successful as well as innovative courses there was one with participants from both Sweden and Canada. The course received funding from the government in 1974 and it contained above all

Table 3. Subjects 1979-1980.

\begin{tabular}{|c|c|c|c|}
\hline \multicolumn{4}{|c|}{ Courses } \\
\hline General course (hours per week) & $\begin{array}{l}\text { Ecology course } \\
\text { (hours per week) }\end{array}$ & $\begin{array}{c}\text { Sami Ällin } \\
\text { (hours per week) }\end{array}$ & $\begin{array}{l}\text { Crafts Course } \\
\text { (hours per week) }\end{array}$ \\
\hline Swedish (4) & Ecology (16) & Sami languages (8) & Colour and shape (4) \\
\hline Mathematics(4) & Communication (4) & History (2) & Sami languages (2) \\
\hline English (4) & Politics and society (4) & Civics (2) & History (2) \\
\hline Literature(2) & Cultural orientation (2) & Religion (1) & Art history (2) \\
\hline Religion (1) & Music (1) & Culture history (2) & Literature(2) \\
\hline Physics (2) & Physical education (1) & Literature(2) & Crafts (24) \\
\hline Chemistry (2) & & Music (1) & \\
\hline Biology (2) & & Crafts (2) & \\
\hline Civics (3) & & Projects (6) & \\
\hline \multicolumn{4}{|l|}{ History (2) } \\
\hline \multicolumn{4}{|l|}{ Psychology (2) } \\
\hline \multicolumn{4}{|l|}{ Music (1) } \\
\hline \multicolumn{4}{|l|}{ Physical education (1) } \\
\hline \multicolumn{4}{|c|}{ Knowledge in managing an association $(1+1)$} \\
\hline \multicolumn{4}{|l|}{ Cultural orientation (2) } \\
\hline Sum: 33 & Sum: 28 & Sum: 26 & Sum: 36 \\
\hline
\end{tabular}

Source: Samernas folkhögskola F7C:2 Planeringar 1977-1978. 
different kinds of crafts from the traditions of the indigenous people of the two countries.

The Sami Folk high school of the 1970s attracted students of different kinds and from different places, above all to the general course and to the ecology course. The Sami students were mostly attracted to Sami Ällin and to the Sami crafts course. The increased amount of students meant that the financial problems of the 1960s were less severe, but some problems remained. A course could have pupils enough, but there could still be subjects where there was too few students, especially the Sami languages. Some of them attracted just a handful of students each year, but still required teachers and other staff members with knowledge in the languages. During the SMS's management, this problem was at best solved through workshops, and with competent teachers who at times visited the school as guest teachers. With a higher level of ambition in the 1970s there was an increased need for teachers competent in the Sami languages. This need was met in part by the fact that an increasing number of the staff, not just teachers, were of Sami decent. Even so, there were still people at the school who had the opinion that the education in Sami languages was not satisfactory. This was one of the reasons for the "language-boycott" that started in fall of 1978. Even though it lasted for less than a year it affected the Folk high school well in to the 1980-ies.

\subsubsection{The Language Boycott}

The 20th October 1978 the Sami Folkhigh school received a document that stated that a number of Sami in Sweden, with an academic degree in the Sami languages, now boycotted the school. The boycotters explained that they would not in any way contribute to translation or education at the Sami high school. The reason for this being that the school had employed two members of the staff that was not fluent in Sami: one accountant and one teacher. Their claimed lack of language competence was seen as a violation of the statutes of the foundation governing the Sami Folkhigh school which said that the school should preserve and develop the Sami culture and that those who work at Sami institutions should have knowledge in the Sami language. The school received the boycott document, as well as the resignation from a teacher with a large amount of classes in Sami languages and in subjects containing Sami culture. This created problems for the school since a substitute could not be found despite several attempts to find one. Therefore the Sami Ällin course and the education in Sami languages was reorganized. The principal, IngwarÅhren, and his staff had to manage those problems and answer to the Swedish national school authority's questions about the process leading to the contested teacher's employment and the measures taken when reorganizing the Sami Ällin course. The questions were asked because applicants to the post as teacher and students at the school had filed complaints against the schools executives regarding the procedure regarding the appointment and the changed curriculum. The school authority came to the conclusion that there was no fault made when reorganizing the education. But, when it came to the employed teacher, none one of the applicants had sufficient merits to qualify for a permanent employment. Not the one that got the post, and not the ones who were runners up. Therefore the school authority would not take any measures against the school.

The following year, 1979, the situation at the Sami Folkhigh school settled. The boycott was called off when the questioned teacher resigned, and one of her contestants (and boycotter) was given the position instead as a temporary employed teacher. So when the school year of 1979-1980 started there was teachers competent in Sami languages, but the Sami Ällin-course seems to have faded away during the boycott. In the spring of 1981 the board of the Sami Folkhigh school however discussed admission rules for the school, and then the Sami Ällin course was mentioned as one of the four courses at the school. In the end of the spring of 1981 the board decided what courses that was to be given during the following school year. Then the Sami Ällin was described as a variant of the general course.

It seems that the problems during the boycott did not affect the number of students in 1978 and the following years. The general courses' students increased as Sami Ällin became a branch of the general course. There was a constant interest in the general course up to the study year 1981-1982, when there was considerably fewer students. Judging from the schools own investigations, no single group of students got a lesser interest in that particular course. The Sami Folkhigh school as a whole had approximately 70 pupils per year prior to 1980 . 1981-1982 meant a decrease with roughly 20 students. The decrease was largest among the students of the general course, while interest in the crafts course remained constant. In the beginning of the 1980s there was a declining interest in the general subjects as well in subjects regarding Sami immaterial culture. The crafts course still attracted students though. This tendency was noticeable among the workshops and other shorter courses as well. For example a workshop in crafts almost always implemented, but almost never studies of Sami literature 
or music.

So in conclusion, when the Swedish national school authority changed the regulations, making it easier to get funding for courses other than the general course, the staff at the Sami Folkhigh school introduced courses that had even more of Sami character. This change appealed to those interested and the number of students increased. It was not so much a change at the ideological level of the curriculum, but a change at the second level: the formal level. That made the change at the third level possible. These changes meant that that the courses at the folk high school in two cases clearly had a Sami content and the other two had some Sami content. But, the curriculum for these courses was not solely conceived from a Sami perspective. The general course and the ecology course were open for students of all backgrounds, but all four courses had to be approved by the national school authority.

\subsection{Language}

Keskitalo and Määttä explains that the Sami language is important for the culture and the individual's identity as well. They also describe teaching methods suitable for teaching the Sami languages as well as revitalization them today: language immersion methods and language nest solutions (Keskitalo \& Määttä, 2011). Language immersion is often used as a method for learning a second language in the natural environment for that language and the language nest method is a method used for revitalization of a language. These method can be used with great success for the Sami. The Sami students often have various knowledge in their language and these methods means that more skilled students can help the others, the teachers more often uses one to one communication with the student rather than teaching a whole class, and the language is used in ordinary situations, not just during a class of language education (Keskitalo \& Määttä, 2011).

These teaching methods were not articulated as methods for language education during the researched period. But, the Sami Folkhigh school never the less came to apply such methods to some extent. This was more out of necessity rather than a pedagogical plan. During the years of the SMS's management there were few permanently employed teachers, and those who were had no, or limited knowledge in a Sami language. The temporarily employed teachers on the other hand were often of Sami decent which meant that there often was somebody at the school with knowledge in the languages, but rarely all Sami languages. This meant a lack in continuity for the language education. However, the staff's tried to find a solution for the language education that could be described as a version of the language immersion method-workshops where students taught each other, at times with the aid of an expert from a university or together with somebody with some skills in the language.

When the foundation started to manage the school the number of students increased and so did the staff. Not only were more people employed, they were to a greater extent of Sami decent. This meant that the language education became more consistent with teachers who were skilled in the Sami languages and permanently employed. This also meant that the teaching on one hand became more like the teaching in any other subject, and to a lesser degree an education in the line of the methods that are preferred today. On the other hand, since more of those employed at the school had some skills and knowledge in a Sami language, it was easier for students or staff to use the language in everyday situations. Despite this improvement not all students were content with the situation and the fact that not all employed at the school were competent in Sami languages was one of the reasons for the language-boycott described earlier. That episode had several causes, the language being one of them. On that occasion some pupils were a part of the boycott, but not many. However the pupils had raised their voices previously which is summarized in a letter to the board of the foundation managing the school. In their letter the student council explain that they have tried to find a solution regarding the language education together with the teachers' council but with no result. Therefore the student council wished to discuss the issue with the board in 1977. The protocol from the school board's meeting describes the pupils' wishes as well as the board's answer.

The student council focused on five issues, not all regarding the language issue: need for interpretation for students lacking knowledge in Swedish, the need for differentiation of the language education, the need for differentiation in the subject Sami history, the lack of possibilities to study the South-Sami language as promised, admission requirements in the courses Sami Ällin and crafts. In their protocol from eight February 1977 the board views the students' wishes as legitimate, but hard to meet due to the lack of resources and governmental regulations. The boards meeting 23 May 1977 discussed the language issue and the pupils once more, and due to the changed rules for how the governments funding could be used they could argue for a solution for one of the 
problems. One person could be hired part time as a teacher and an aid for the students in questions regarding languages. Since the language boycott was imposed 1978 one could assume that the situation was not solved to the liking of all at the school.

There was always a will to offer the school's students the opportunity to improve their skills in their Sami language during the period of 1942-1982. The principal and the other members of the staff tried to offer the best possible language education possible, but not only did the lack of means made this difficult. There was always a problem finding qualified teachers for the smaller languages, and there was never literature suitable for all aspects of the language education. There were complaints from the students at times and the good intentions were not always turned in to reality. This situation was due to external conditions, particularly the allocated resources.

\subsection{Teaching Arrangements}

It can be argued weather or not there are a pedagogy that are less or more suitable for young people of an indigenous minority than other students. Keskitalo and Määttä do not reason about that, but describe how teaching should be organized for young Sami and compare it to how teaching is mostly organized in the Western societies. The Sami have a circular conception of time, guided by the sun rather than the clock, so usual linear arrangement of time in the schools with 45 minute lessons is not ideal. Furthermore, Keskitalo and Mättä describe the problem with physical organization. The school often contains lessons in classrooms, whist the Sami need a connection with the nature and the students learned knowledge needs to be of use outside of the classroom. The two authors also point out the teaching methods as something that may be problematic. In the western society the school is authoritative, and the schools teaching arrangements' are closed with timetables organized into subjects and teaching centered methods. A Sami pedagogy is the opposite, it utilizes pupil centered learning methods, it is flexible and knowledge is not something that is handed over from an authority but something that is a result from a negotiation or discussion. Theme-based teaching with teachers who functions as guides rather than lectures is another feature (Keskitalo \& Määttä, 2011).

Keskitalo and Määttä's description of a teaching to suit the Sami is based on social constructivism. That school of taught on of how students learn did not fully influence the Swedish educational system until the 1990s so it is no wonder that the Sami Folk high school did not follow the model completely. But, the Folk high schools in general did not have the same rigid timetables to follow like the primary schools did and even though the SMS had a more conservative view on many things than other organizations managing schools, their Folk high school had many learning activities that stands out as modern. Furthermore the staff often organized field trips and organized teaching that was of practical use for many Sami pupils. The principal, Wallmark, led discussions on current topics of interest of the young Sami and he was interested in gaining knowledge in many things regarding the Sami culture. This tradition was kept when the management was handed over to the foundation.

When the foundation started their management of the school and Östlund was the headmaster the teaching arrangements did not change much. There were more courses offered to the would-be students, but there was still a timetable for each course that was followed. The journals shows few deviations during the period 1942-1982 but there are some. These was mostly due to field trips and so forth. When the foundation took over the management there was not much change in the subjects matter nor the teaching methods, but it there clearly was a change in attitude. There was a change in the management and it seems that the students, as well as some members of the staff, became more critical in their attitude to society at large and also how Sami organizations handled their commission. The apparent example being the previously described language boycott, where the schools board and the board of its managing foundation received critique as well. The student council made a resolution in October 1978 saying that they wanted to have some influence when a new member of the staff was about to be employed. They also viewed Sami languages as the languages that should be used at the Folk high school and that when hiring personnel, their skills in a Sami language should be an important merit. So, the change in the management did not induce any significant change in how teaching was arranged, but got the consequence that students articulated their position to a greater extent.

\subsection{Extensive Cooperation}

The final core factor that Keskitalo and Määttä describes is a cooperation between the school and the community. The pedagogical principles for Sami education should be grounded in the Samis own culture and values. In cooperation with the community it should be decided when, where and why a student should learn one thing or 
another. A suitable way for the schools to get aid from parents and the rest of the community is to organize a hearing. The needed changes demands a lot from the teachers. Keskitalo and Määttä points out that the teacher education programs must change so it supports an altered teacher role - the supervisor of learning situations rather than the authoritative teacher. It is also important that the teacher not only is skillful. The teacher must also have insights in the culture and language of the indigenous people (Keskitalo \& Määttä, 2011).

Keskitalo's and Määttä's main concern is the primary education but their thoughts could also be applied to secondary education or adult education. Even though parents are always important, the most important partners to cooperate with for school that educates adolescents or adults could be organizations, workplaces, authorities as well as individuals who represent or influences the indigenous people's culture or professional life. This sort of cooperation was something that all principals during the period 1942-1982 was committed to. Wallmark sought to cooperate with individuals and organizations who he thought might be of use for his students' education. His quest was to improve the students' chances on the labour market as well as to gain insights in their own culture, and he hoped that they themselves eventually would work for that. In order to achieve that he worked hard himself to learn and also cooperated with reindeer herders, researchers, Sami politicians, craftsmen and many other. The next principal, Birgitta Östund not only, in this aspect, followed Wallmarks example, but she also extended it to cooperation with indigenous peoples in Canada. But, no matter how hard they worked, since Wallmark and Östlund was not of Sami decent. Therefore they were not fully qualified for their job according to the standards of Keskitalo and Määttä. Their successors did, since they were Sami themselves.

It is difficult to say that Ingwar Åhren's and Per Mikael Utsi's years as principals during this research period deviated much in this aspect from the work that Wallmark and Östlund did. But there was one important difference. Over the years more and more of those employed at the school were Sami themselves. This meant that Sami culture, values and so forth was present to a greater degree than earlier. On the other hand, this also meant that there was many more kinds of Sami cultures and Sami interests that was present than before. The language boycott showed that this was not completely without conflict and not easy to deal with.

\section{Conclusion}

This description of forty years of teaching at the Sami Folk high school shows that some things changed and others remained the same. The major change in the investigated 40 years is the increasing Sami self-determination. The largest step in that direction occurred in 1972 when the SMS handed over the management of the Sami Folk high school to a foundation where Sami organizations were represented. During the following years, more and more of the employed personnel at the school was of Sami decent. The first principal of Sami origin was employed in 1975. During the first years of the 1970s, the number of courses offered at the school changed, from one to four. This was due to changes in the regulations of the national school authority, making it possible to receive funds for other courses than the general course. At the same time the attitude among the students and some of the staff became more radical. This change had to do with the changes at the Sami Folk high school, and also the changes in the Swedish society at large. Keskitalos and Määttä model for Sami pedagogy describes both internal and external factors that affected the teaching. In the case of the Sami Folkhigh school, the most important external factors was self-determination, and issues of curriculum and language were important internal factors.

During the decades following the Second World War the Swedish society changed a lot, especially the educational system. Secondary education became more accessible to young people of all backgrounds. At the same time, religion lost its position in the society. Workplaces, schools and other institutions became less authoritarian. During the end of the 1960s, there was a high degree of political interest and involvement among Swedish adolescents, as well as in other parts of the Western world. This political interest continued in to the 1970s with a focus to some extent moving to environmental issues. Young Sami was no exception from this trend. The Sami Folk high school did probably not seem as a particularly attractive option during the 1960s for young Sami who wanted to educate themselves due to the SMS's management, somewhat authoritarian and religiously influenced. The Sami youth had many options, something that was not the case during the 1950s for example. When the students did not come in large enough numbers, the school got financial problems, which ultimately meant that the foundation took over the management of the school. This change had the effect that students once again found their way to the Sami Folk high school. However, trends in the society at large are only part of the 
explanation for the events at the Sami Folkhigh school.

The four different courses that were conceived by the staff at the school also had had an effect on the number of students. This change in the offered courses was due to the altered role of the Swedish Folk high schools. The Swedish school authorities changed the regulations, making it possible to offer longer courses that could have other purposes than just increasing the educational level of the student. As long as the Folk high school offered the general course, and the curriculum of a course was approved by the Swedish school authorities, it could be funded by governmental means. This change meant that the staff could design two courses which were dominated by themes of Sami culture. One of them in crafts and the other one concentrated on the immaterial parts of Sami culture. These courses were supplemented with an ecology course that would capture a growing interest in environmental issues and tourism in the north. The general course was still offered, but without Sami handicrafts and Sami languages. For those who wanted to, it was however possibly to study Sami languages, but it was not mandatory.

The two Sami courses, Sami Ällin and Sami crafts, were concentrated on teaching various aspects of the Sami culture. But, their curriculum contained other school subjects as well. Keskitalo and Määttä explain that a curriculum should ideally take into account both the Sami culture as well as western knowledge. Although the school management during the time of the SMS tried to incorporate both aspects, but they did not fully succeed. The rules of the national school authorities made it impossible and they had to follow them due to financial issues. The two Sami oriented courses that started in the 1970s, Sami Ällin and Sami crafts, were a kind of mixture of western knowledge and indigenous culture, language and traditional knowledge that Keskitalo and Määttäwant for Sami schools today.

A Curriculum works at many levels and is more than syllabuses, schedules, and the official aims of an education. It also involves the teachers' interpretations of the curriculum, and the students' experiences of the teaching. In order to describe the hidden curriculum of the Sami high school, more sources and sources of different kinds should be studied. However it can be said that regarding the everyday use and teaching of Sami languages, there clearly was experiences that contradicted the Foundation's statements regarding Sami languages and culture.

According to Keskitalo and Määttä, it is imperative that the Sami language is an integral part of teaching the Sami. The staff of the Sami Folk high school had that idea from the beginning. However, it was a constant problem to get hold of qualified teachers, a situation that improved in the 1970s. During that decade, there were greater demands from the students regarding the teaching and the use of Sami languages during all activities at the school. The languages became something of a symbolic issue, not least in the context of the language boycott in 1978. This action had the languages in focus, but it also focused on who was to be employed or not, and other issues of rivalry at the school became visible. The situation came to a settlement in 1979, but it affected the school the following years.

During the period 1942 to 1982 the Sami Folk high school played an important role for many individual Sami and for the whole Sami people. One of the most important functions was as a meeting place, a place was the most important Sami organizations have been founded (Lantto, 2000). It also offered a possibility for many young Sami to educate themselves and gain access to higher education. The Folk high school educated the Sami in general school subjects. It also aided young Sami in learning their culture helped to preserve and develop the culture as well. In doing so, many skilled craftsmen and speakers of the Sami languages, could earn a living, at least for a period of their life. This was especially the case after 1972 when the foundation started their management of the school and it was possible for the school to employ more teachers, many of them being Sami. This increased the Sami Folk high school's importance even more as an institution that preserved and developed the Sami culture. The research that has been presented in this article has shown that the Sami Folk high school during the first 30 years had the best of intentions, but the management did not have the possibilities to offer an education that totally suited the needs of the Sami and lacked in Sami influence over the education as well. During the ten years that followed, the Sami influence increased and so did the possibilities to increase the amount of Sami cultural education for the student that wanted that element in his or her education. By all indications this development has continued to this day. Now the school offers courses that are concentrated on Sami culture and vocations, and the autonomy for the school has increased a lot. For example, it is no longer required that a general course is offered. However, that development is outside the frameworks of the researched period of this study. 


\section{Acknowledgements}

This article could not have been written without founding from the Swedish Research Council and the Research Council FORMAS. I would also like to thank friends and colleagues at the Centre for Sami Research (CESAM/ Vaartoe) and the Department of historical, philosophical and religious studies at Umeå University for comments and interesting discussions.

\section{References}

Burgman, H. (1968). Folkskolanoch den pedagogiskautvecklingen 1868-1918 (The Folk School and the Pedagogical Development). In A. Degerman, H. Burgman, \& P. Terning (Eds.), Svenskfolkhögskola 100 år. D. 3. (Swedish Folk High School 100 years) (pp. 123-139). Stockholm: Liber.

Hirvonen, V. (2004). Sami culture and the School: Reflections by Sami Teachers and the Realization of the Sami School. Kárásjohka: Saami University College.

Keskitalo, P., \& Määttä, K. (2011). Sámi pedagogihkaiešvuođat, Saamelaispedagogiikanperusteet, The basics of Sámi pedagogy, Grunderna i samiskpedagogik, Osnovysaamskojpedagogiki. Rovaniemi: Lapin yliopistokustannus.

Keskitalo, P., Määttä, K., \& Uusiautti, S. (2011). Toward the Practical Framework of Sámi Education. British Journal of Educational Research, 1, 84-106.

Lantto, P. (2000). Tiden börjar på nytt: en analys av samernas etnopolitiska mobilisering i Sverige 1900-1950 (Time Begins Anew. An Analysis of the Ethnopolitical Mobilization among the Sami in Sweden 1900-1950). Ph.D. Thesis, Umeå: Umeåuniversitet.

Morris, K. (2009). Loss of Land Could Threaten the Sami People. The Lancet, 374, 15-16. http://dx.doi.org/10.1016/S0140-6736(09)61219-8

Östlund, B. (1971). Samernas folkhögskola 1970-1971 (The Sami Folk High School 1970-1971). Jokkmokk: Samernas folkhögskola.

Samernas Utbildningscentrum (2013). “Samernas” 70 år i samernastjänst: Jubileumstidning, Sámijåhpadusguovdasj (“The Sami's” 70 Years of Service to the Sami: Anniversary Magazine). Jokkmokk: Samernasutbildningscentrum.

Sametinget (2005). The Sami: An Indigenous People in Sweden. Kiruna: Sami Parliament. http://www.samer.se/2137

SCB (1977). Elever i icke-obligatoriska skolor 1864-1970 (Pupils in Secondary Schools in Sweden 1864-1970). http://www.scb.se/Grupp/Hitta_statistik/Historisk_statistik/_Dokument/Elever-i-icke-obligatoriska-skolor-1864-1970.pdf

Sjögren, D. (2010). Den säkra zonen: Motiv, åtgärdsförslag och verksamhet i den särskiljande utbildningspolitiken för inhemska minoriteter 1913-1962 (The Safety Zone : Motives, Suggested Measures and Activities in the Separative Education Policy Targeted at Native Minorities [in Sweden] 1913-1962). Ph.D. Thesis, Umeå: Umeå Universitet.

Sjölander, P., Edin-Liljegren, A., \& Daerga, L. (2009). Samernas hälsosituation i Sverige: En kunskapsöversikt (The Health Situation of the Sami: An Evaluation of Knowledge). Lycksele: Södra Lapplands forskningsenhet, på uppdrag av Sametinget. http://www.sametinget.se/40268

Svenska Missionssällskapet (1942). Samernas folkhögskola (The Sami Folk High School). Sorsele, 3-6.

Toivalainen, T. (1995). A Comparative Study of Nordic Folk High Schools and the Highlander Folk School. Convergence, 28, 5-24.

Wallmark, L. (1956). Samernas folkhögskola-Redogörelseförläsåret 1955-1956 (The Sami Folk High School-Report from the School Year 1955-1956). Jokkmokk: Samernas folkhögskola.

Wallmark, L. (1961). Samernas folkhögskola—Redogörelseförläsåret 1960-1961 (The Sami Folk High School—Report from the School Year 1960-1961). Jokkmokk: Samernas folkhögskola.

Wallmark, L. (1966). Samernas folkhögskola-Redogörelseförläsåret 1965-1966 (The Sami Folk High School-Report from the School Year 1965-1966). Jokkmokk: Samernas folkhögskola.

Wallmark, L. (1969). Samernas folkhögskola-Redogörelseförläsåret 1968-1969 (The Sami Folk High School-Report from the School Year 1968-1969). Jokkmokk: Samernas folkhögskola.

Wallmark, L. (1970). Samernas folkhögskola-Redogörelseförläsåret 1969-1970 (The Sami Folk High School—Report from the School Year 1969-1970). Jokkmokk: Samernas folkhögskola. 


\section{Archives}

Jokkmokk, Ájtte [Jokkmokk, Ájtte] Samernas folkhögskola—Svenska Missionssällskapet, F2:12 Undervisningsjournaler 2:a läsåret 1947-1951. [The Sami Folk High School—Swedish Mission Society, F2:12 Teaching Journals, Second School Year 1947-1951].

Jokkmokk, Ájtte [Jokkmokk, Ájtte] Samernas folkhögskola—Svenska Missionssällskapet, F2:12 Undervisningsjournaler 1:a läsåret 1962-1970. [The Sami Folk High School—Swedish Mission Society, F2:12 Teaching Journals, First School Year 1962-1970].

Jokkmokk, Samernas folkhögskola/Samernas utbildningscentrum, [Jokkmokk, The Sami Folk High School/The Sami Educational Centre] Samernas folkhögskola A1:1, Protokoll Samernas folkhögskolas stiftelse 1972-1981. [The Sami Folk High School A1:1 Protocol. The Foundation of the Sami Folk High School 1972-1981].

Jokkmokk, Samernas folkhögskola/Samernas utbildningscentrum, [Jokkmokk, The Sami Folk High School/The Sami Educational Centre] Samernas folkhögskola A1:3, Protokoll med bilagor styrelsen 1976. [The Sami Folk High School A1:3 Protocols with Supplements, the Board 1976].

Jokkmokk, Samernas folkhögskola/Samernas utbildningscentrum, [Jokkmokk, The Sami Folk High School/The Sami Educational Centre] Samernas folkhögskola A1:6, Protokoll skolstyrelse 1979-1980. [The Sami Folk High School A1:6, Pro-tocol School Board 1979-1980].

Jokkmokk, Samernas folkhögskola/Samernas utbildningscentrum, [Jokkmokk, The Sami Folk High School/The Sami Educational Centre] Samernas folkhögskola A1:7, Protokoll skolstyrelsens arbetsutskott 1979-1981. [The Sami Folk High School A1:7, Protocoll School Board’s Working Committee 1979-1980].

Jokkmokk, Samernas folkhögskola/Samernas utbildningscentrum, [Jokkmokk, The Sami Folk High School/The Sami Educational Centre] Samernas folkhögskola A1:9, Protokoll Arbetsutskottet, styrelsen, stiftelsen 1981-83. [The Sami Folk High School A1:9, Protocol Working Committee, the Board, the Foundation 1981-1983].

Jokkmokk, Samernas folkhögskola/Samernas utbildningscentrum, [Jokkmokk, The Sami Folk High School/The Sami Educational Centre] Samernas folkhögskola E1:1, Diarieförda skrivelser 1972-1973. [The Sami Folk High School E1:1, Regis-tered Correspondence 1972-1973].

Jokkmokk, Samernas folkhögskola/Samernas utbildningscentrum, [Jokkmokk, The Sami Folk High School/The Sami Educational Centre] Samernas folkhögskola E1:11, Diarieförda skrivelser, 1978. [The Sami Folk High School E1:11, Regis-tered Correspondence, 1978].

Jokkmokk, Samernas folkhögskola/Samernas utbildningscentrum, [Jokkmokk, The Sami Folk High School/The Sami Educational Centre] Samernas folkhögskola E1:12, Diarieförda skrivelser, 1978. [The Sami Folk High School E1:12, Regis-tered Correspondence, 1978].

Jokkmokk, Samernas folkhögskola/Samernas utbildningscentrum, [Jokkmokk, The Sami Folk High School/The Sami Educational Centre]Samernas folkhögskola E1:13, Skrivelser, Vol. 1 1979. [The Sami Folk High School E1:13, Registered Correspondence, Vol 1 1979].

Jokkmokk, Samernas folkhögskola/Samernas utbildningscentrum, [Jokkmokk, The Sami Folk High School/The Sami Educational Centre] Samernas folkhögskola E1:14, Skrivelser, Vol. 2. 1979. [The Sami Folk High School, E1:14, Corre-spondence].

Jokkmokk, Samernas folkhögskola/Samernas utbildningscentrum, [Jokkmokk, The Sami Folk High School/The Sami Educational Centre] Samernas folkhögskola F6B:1 Korta kurser 1977-1978. [The Sami Folk High School F6B:1 Short Courses 1977-1978].

Jokkmokk, Samernas folkhögskola/Samernas utbildningscentrum, [Jokkmokk, The Sami Folk High School/The Sami Educational Centre] Samernas folkhögskola F6B:2 Korta kurser 1979-1980. [The Sami Folk High School F6B:2 Short Courses 1979-1980].

Jokkmokk, Samernas folkhögskola/Samernas utbildningscentrum, [Jokkmokk, The Sami Folk High School/The Sami Educational Centre] Samernas folkhögskola F7C:2, Planeringar med mera (Långa kurser) 1977-1983. [The Sami Folk High School, Planning etcetera (Long Courses) 1977-1983].

Jokkmokk, Samernas folkhögskola/Samernas utbildningscentrum, [Jokkmokk, The Sami Folk High School/The Sami Educational Centre] Samernas folkhögskola Ö2:1, Samiska frågor. [The Sami Folk High School Ö2:1, Sami Issues].

Jokkmokk, Samernas folkhögskola/Samernas utbildningscentrum, [Jokkmokk, The Sami Folk High School/The Sami Educational Centre] Samernas folkhögskola, A1:4 Protokoll styrelsens arbetsutskott 1977-1979. [The Sami Folk High School, A1:4 Protocol the Boards Working Committee 1977-1979].

Jokkmokk, Samernas folkhögskola/Samernas utbildningscentrum, [Jokkmokk, The Sami Folk High School/The Sami Educational Centre] Samernas folkhögskola, F7A:1 Långa kurser 1972-1973. [The Sami Folk High School, F7A:1 Long 
Courses 1972-1973].

Jokkmokk, Samernas folkhögskola/Samernas utbildningscentrum, [Jokkmokk, The Sami Folk High School/The Sami Educational Centre] Samernas folkhögskola, F7A:2 Långa kurser 1974-1982. [The Sami Folk High School, F7A:2 Long Courses 1974-1982]. 